\title{
HAIWAN $\boldsymbol{J} A L L \bar{A} L A H$ DARI PERSPEKTIF ISLAM: ANALISIS FATWA MALAYSIA DAN NEGARA BRUNEI DARUSSALAM
}

\author{
Jallālah Animal from Islamic Perspective: An \\ Analysis on Malaysian and Brunei Darussalam \\ Fatwa
}

\author{
Norhidayah Pauzi * \\ Saadan Man $* *$
}

\begin{abstract}
Feeding aquatic animal with non-halal food is frequently practised by a handful of breeders within and outside the country. Accordingly, the Malaysian National Fatwa Council Committee has issued a fatwa that the consumption of jallālah animals as haram or unlawful. However, the Mufti of Brunei Darussalam has come up with a different fatwa describing the consumption of jallālah animals as permissible and lawful in Islam. The difference of fatwas regarding halal or lawful status of the consumption jallalah animals has indeed created confusion to the Muslim community in Malaysia. This research focuses on the concept of jallālah animals from the Islamic perspective and analysis on the fatwas in Malaysia and Brunei Darussalam pertaining to the issue. The methodology used in this study is the method of documentation and observation. From the study,
\end{abstract}

\footnotetext{
* Calon Phd., Jabatan Fiqh dan Usul, Akademi Pengajian Islam, Universiti Malaya,da_my85@um.edu.my

** Pensyarah Kanan, Fiqh dan Usul, Akademi Pengajian Islam, Universiti Malaya,saadan@um.edu.my
} 
it is found that two main factors contribute to the differences in fatwas on jallālah animals between Malaysia and Brunei Darussalam, i.e. - the different standards of halal food: MS1500:2009 and PBD 24:2007; and different sources of literature references by both parties.

Keywords: Jallālah, Fatwa, Fiqh, Standard, Harus

\section{PENDAHULUAN}

Penternakan ikan air tawar mampu menjana pendapatan lumayan dalam sektor perikanan negara. Ia semakin mendapat permintaan ramai terutamanya penternakan ikan air tawar kerana harganya lebih murah dan rasanya yang sedap selain mudah dibiakkan, cepat membesar, tahan lasak dan modal yang rendah. Akan tetapi, Jabatan Perikanan Malaysia memaklumkan terdapat segelintir penternak ikan air tawar di Malaysia mengamalkan aktiviti ternakan yang tidak bertanggungjawab untuk mengurangkan kos operasi. Salah satu aktiviti tersebut adalah dengan memberikan ikan air tawar yang diternak dengan bahan makanan tidak halal. Antara bahan yang dimaksudkan organ haiwan yang tidak disembelih secara syarak, lebihan daripada pusat sembelihan babi, bangkai seperti ayam atau babi dan sisa restoran bukan Islam. ${ }^{1}$ Berhubung dengan isu ini, Muzakarah Jawatankuasa Fatwa Kebangsaan Malaysia memutuskan penternakan ikan air tawar yang diternak di dalam kolam ternakan adalah haram dimakan sekiranya ikan tersebut sengaja dipelihara di dalam air najis atau sengaja diberikan makan najis seperti daging babi, bangkai dan lain-lain. ${ }^{2}$ Sebaliknya, Fatwa Mufti Kerajaan Brunei Darussalam menyifatkan ikan yang diberikan makanan yang tidak halal oleh penternak adalah makruh. ${ }^{3}$ Justeru, perbezaan fatwa di antara dua negara ini akan dibincangkan dalam kajian ini. Ia dapat mengharmonikan perbezaan fatwa dan menjelaskan kekeliruan masyarakat awam terhadap isu ini.

\footnotetext{
$1 \quad$ Kertas untuk Pertimbangan Muzakarah Jawatankuasa Fatwa Majlis Kebangsaan Bagi Hal Ehwal Ugama Islam Malaysia, 2.

2 Ibid.

3 Fatwa Mufti Kerajaan Negara Brunei Darussalam, Makan Ikan Yang Diberi Makan Najis, Siri Fatwa 35/2006.
} 


\section{LATAR BELAKANG STATUS KESUCIAN IKAN YANG DIBERIKAN MAKANAN TIDAK HALAL}

Isu status kesucian ikan yang diberikan makanan tidak halal bermula apabila Harian Metro pada 7 Januari 2006 telah mendedahkan di muka depan akhbarnya tentang "Patin Babi Rebus." Laporan tersebut menyatakan terdapat beberapa pengusaha ikan air tawar terutamanya patin di Perak menggunakan usus dan organ dalaman babi yang direbus sebagai makanan untuk ternakan mereka. Usus yang direbus itu dicampur dengan jagung bagi membolehkan ikan membesar dengan cepat sebelum dijual di pasaran tempatan mahupun luar negara. Antara pasaran ikan ternakan tersebut ialah sekitar Perak, Kuala Lumpur, Selangor, Melaka, Negeri Sembilan dan Johor. Manakala luar negara pula ialah di Timur Tengah kerana produk dari negara Islam seperti Malaysia lebih mudah menembusi pasaran mereka. ${ }^{4}$

Berita Harian pada 18 Januari 2006 telah melaporkan bahawa dalam operasi yang dijalankan oleh Jabatan Agama Islam Perak ke kolam ternakan ikan di Tronoh, Papan dan Batu Gajah apabila mereka mendapati penternak menggunakan rebusan daging babi, sisa ayam dan tahi ayam sebagai bahan makanan utama kepada ikan yang diternak khususnya ikan air tawar jenis patin, tilapia dan keli Afrika. Ikan-ikan tersebut sebelum dijual akan dilepaskan ke dalam sungai di Pahang selama sebulan, bertujuan menghilangkan bau hanyir sebelum dipasarkan. ${ }^{5}$ Tindakan memberi ikan ternakan makan dengan daging babi dikatakan dapat mempercepatkan tumbesaran ikan dan dapat dipasarkan dalam tempoh tiga bulan berbanding setahun jika tidak diberi makanan berkenaan. ${ }^{6} \mathrm{Di}$ samping itu juga, pada 9 Julai 2014, terdapat beberapa pengusaha kolam ikan di sekitar Shah Alam disyaki menjadikan bangkai babi sebagai makanan ikan yang diternak mereka. Sehari sebelum

$4 \quad$ Kertas untuk Pertimbangan Muzakarah Jawatankuasa Fatwa Majlis Kebangsaan Bagi Hal Ehwal Ugama Islam Malaysia, 2.

5 Bernama, "Waspada Beli Ikan Air Tawar Diberi Makan Daging Babi," laman sesawang Kementerian Perdagangan Dalam Negeri, Koperasi dan Kepenggunaan, dicapai 16 Januari 2015, http:// kpdnkk.bernama.com/newsBm.php?id=175968\&.

6 Kertas untuk Pertimbangan Muzakarah Jawatankuasa Fatwa Majlis Kebangsaan Bagi Hal Ehwal Ugama Islam Malaysia, Kertas JKF Bil. 2/73/2006, 2. 
kejadian dilaporkan, tengkorak dan tulang babi telah dikesan di dasar sebuah kolam ternakan ikan di Perak selepas ianya pecah dan kering.

\section{FATWA-FATWA STATUS KESUCIAN IKAN YANG DIBERIKAN MAKANAN TIDAK HALAL ANTARA MALAYSIA DAN NEGARA BRUNEI DARUSSALAM}

Di Malaysia, Jabatan Perikanan Malaysia telah mengemukakan isu ini kepada Jabatan Kemajuan Islam Malaysia (JAKIM) melalui Bahagian Hab Halal untuk mengadakan penyelidikan dan penjelasanhukummengenainya.Olehyang demikian, perbincangan mengenai status kesucian haiwan jallālah telah dibincangkan oleh ahli jawatankuasa fatwa di peringkat kebangsaan dan negeri.

Berasaskan keputusan fatwa daripada Muzakarah Jawatankuasa Fatwa Majlis Kebangsaan Bagi Hal Ehwal Ugama Islam Malaysia, hasil perbincangan telah memutuskan seperti berikut:

Muzakarah Jawatankuasa Fatwa Majlis Kebangsaan
Bagi Hal Ehwal Ugama Islam Malaysia Kali Ke-73
yang bersidang pada 4 hingga 6 April 2006 telah
membincangkan status kesucian ikan yang diberi
makanan tidak halal. Muzakarah telah memutuskan
bahawa ikan yang dipelihara di dalam kolam
ternakan dan seumpamanya adalah haram dimakan
sekiranya ikan tersebut sengaja dipelihara di dalam
air najis atau sengaja diberi makan najis seperti
daging babi, bangkai atau sebagainya. ${ }^{7}$

Di samping itu, pada 3 Januari 2007, Seksyen 34 - Akta Pentadbiran Undang-undang Islam(Wilayah-wilayahPersekutuan) 1993 telah mewartakan Status Kesucian Ikan Diberi Makanan Tidak Halal seperti berikut: ${ }^{8}$

$7 \quad$ Kertas untuk Pertimbangan Muzakarah Jawatankuasa Fatwa Majlis Kebangsaan Bagi Hal Ehwal Ugama Islam Malaysia, 11-12.

8 Jabatan Kemajuan Islam Malaysia, "Status Kesucian Ikan Diberi Makanan Tidak Halal," laman sesawang Portal Rasmi Fatwa Malaysia, http://www.e-fatwa.gov.my/fatwa-negeri/status-kesucianikan-diberi-makanan-tidak-halal-1, dicapai 16 Januari 2015. 
Ikan yang dipelihara di dalam kolam ternakan dan seumpamanya adalah haram dimakan sekiranya ikan tersebut sengaja dipelihara di dalam air najis atau sengaja diberi makanan najis seperti daging babi, bangkai dan sebagainya.

Selain itu, pada fatwa yang dikeluarkan oleh Mufti Selangor dan diwartakan pada 25 Oktober 2007 adalah seperti berikut: ${ }^{9}$

Ikan ternakan yang dipelihara dalam kolam, lombong dan seumpamanya serta diberi makanan daripada najis seperti babi dan bangkai sebagai sumber makanan utama adalah haram dimakan; dan

Penternak dilarang memberi ikan ternakan dengan makanan utama daripada najis sebagai langkah di samping menjaga sensitiviti umat Islam.

Mesyuarat Jemaah Ulama' Majlis Agama Islam dan Adat Istiadat Melayu Kelantan yang bersidang pada 21 Disember 2006 telah membincangkan status kesucian ikan yang diberi makanan tidak halal. Mesyuarat telah membuat keputusan bersetuju menfatwakan bahawa ikan yang dipelihara di dalam kolam, tasik, lombong dan seumpamanya serta diberi makanan yang berasal daripada daging babi dan anggota-anggotanya yang lain adalah haram dimakan dan para penternak ikan dilarang memberi ikan ternakan dengan makanan yang berasal daripada daging babi dan anggota-anggotanya sebagai langkah sadd al-dhara ${ }^{\prime} i$ '. ${ }^{10}$

Walau bagaimanapun, fatwa Mufti Kerajaan Brunei Darussalam berkaitan ikan yang diberi makan najis dibahagikan kepada tiga penjelasan: ${ }^{11}$

Pertama, memakan haiwanjallālah. Hukummemakan haiwan jallälah adalah makruh apabila daging dan ususnya berbau seperti bau najis. Tetapi sekiranya daging haiwan jallālah tidak berubah rasa, warna atau bau seperti najis, maka hukum memakannya

\footnotetext{
$9 \quad$ Ibid.

10 Ibid.

11 Fatwa Mufti Kerajaan Negara Brunei Darussalam, "Makan Ikan Yang Diberi Makan Najis," Siri Fatwa (35/2006).
} 
adalah harus sekalipun haiwan jallālah tidak makan kecuali najis sahaja.

Begitu juga, sekiranya haiwan jallālah yang berbau itu dikurung (dikuarantinkan) untuk diberi makanan yang suci sehingga hilang bau atau kesan najis padanya. Kemudian disembelih, maka tidak makruh memakan daging haiwan jallālah. Walau bagaimanapun, kadar had makanan yang diberi kepada haiwan jallālah dan tempoh masa ianya dikurung (dikuarantinkan) untuk menghilangkan hukum makruh tersebut tidaklah ditentukan kadar dan tempohnya. Ia adalah tertakluk kepada adat kebiasaan yang dijangka bauan kesan najis tersebut akan hilang.

Kedua, memberi makanan haiwan yang boleh dimakan dengan makanan najis. Hukum memberikan makanan haiwan yang boleh dimakan dengan najis hukumnya adalah makruh.

Ketiga, menjual haiwan jallālah. Hukum menjual haiwan jallālah yang sudah mati setelah disembelih sebelum dikurung (dikuarantinkan) untuk diberikan makanan suci agar hilang padanya kesan najis, hukumnya adalah makruh kerana penjualan akan menjadi jalan menuju ke arah berlakunya suatu tujuan yang makruh iaitu memakan daging haiwan jallālah yang berubah rasa, warna dan baunya seperti najis. Tetapi haiwan jallālah dijual dalam keadaan hidup di mana ada kesempatan untuk dikuarantinkan untuk diberikan makanan suci agar kesan najis padanya hilang, maka penjualan itu adalah harus.

Berdasarkan fatwa-fatwa di atas, dapat dirumuskan bahawa dalam konteks Malaysia hukum memakan haiwan akuatik yang diberikan makanan tidak halal adalah haram berasaskan keterikatan kepada mazhab Syafii. Di samping itu, ia menerima pakai prinsip sadd al-dhar $\bar{a}$ ' $i$ ' bagi memelihara sensitiviti masyarakat Islam. Manakala, dalam konteks negara luar seperti negara Brunei Darussalam memutuskan bahawa hukum memanfaatkan haiwan akuatik yang diberikan makanan tidak halal adalah makruh apabila 
rasa, bau dan warna terhadap haiwan jallālah berubah kepada najis. Akan tetapi, sekiranya tidak berlaku sebarang perubahan terhadap rasa, bau dan warna haiwan berkenaan hukum memanfaatkannya adalah diharuskan oleh syarak.

\section{ANALISIS PERBANDINGAN FATWA BERHUBUNG STATUS KESUCIAN IKAN YANG DIBERIKAN MAKANAN TIDAK HALAL ANTARA MALAYSIA DAN NEGARA BRUNEI DARUSSALAM}

Para fuqaha telah membincangkan status kesucian ikan yang diberikan makanan tidak halal dalam bab jallālah. Jallālah adalah haiwan yang memakan kotoran. ${ }^{12}$ Mawsū 'ah al-Fiqhiyyah menjelaskan jallālah adalah binatang yang tempat tinggalnya bernajis dan memakan tahi. ${ }^{13}$ Al-Qāmūs al-Fiqhī mentakrifkan haiwan jallälah sebagai semua haiwan berkaki empat yang memakan najis secara mutlak. ${ }^{14}$ Manakala, menurut $M u$ 'jam alMuștalaḥāt wa Alfāz al-Fiqhiyyah, jallālah adalah haiwan yang memakan kotoran yang terdiri daripada unta, lembu, ayam dan seumpamanya. ${ }^{15}$ Haiwan jallälah adalah haiwan yang memakan kotoran dalam kuantiti yang banyak dan terdiri daripada unta, lembu, berbiri, ataupun ayam. ${ }^{16}$ Justeru, haiwan jallālah adalah haiwan yang memakan najis (kotoran seperti tahi dan bangkai haiwan) dengan kerap dan dalam kuantiti yang banyak, ${ }^{17}$ dan tinggal ditempat bernajis sebagai habitatnya, sehingga mempunyai

12 'Ilā' al-Dīn Muḥammad bin Aḥmad al-Samarqandī, Tuhfah alFuqahā' (Bayrūt: Dār al-Kutub al-'Ilmiyyah, t. t.) 3:65.

13 Al-Mawsū 'ah al-Fiqhiyyah, ed. ke-2 (al-Kuwayt: Wizārah al-Awqāf wa al-Syu'ūn al-Islāmiyyah, 2007), 15:260.

14 Sa'di Abū Jayb, al-Qāmūs al-Fiqh Lughatan wa Iștilāhan (Dimasyq: Dār al-Fikr, 2009), 63.

15 Maḥmūd 'Abd al-Raḥman 'Abd al-Mun'im, Mu 'jam al-Muștalahāt wa Alfāz al-Fiqhiyyah (Qāhirah: Dār al-Faḍilah, t. t.), 1:533.

16 Zakariyyā 'Alī Yūsuf, Majmū' Syarh al-Muhadhdhab (t. p.: t. t. p, t. t.), 7:26.

17 Wan Norhana Md. Noordin, "Haiwan Al-Jallalah," http://dbserver. fri.gov.my/portal/portalimages/buku-penerbitan/Kosmik_sep2012_ wan.pdf, dicapai 28 Februari 2014. 
bau yang busuk daripada badannya. ${ }^{18}$ Ia merujuk kepada haiwan ternakan seperti unta, lembu, kambing, ayam dan lain-lainnya. ${ }^{19}$

Tindakan segelintir penternak yang menyediakan makanan tidak halal kepada haiwan ternakan khususnya haiwan akuatik adalah suatu yang tidak wajar dipraktikkan dalam penternakan haiwan. Perbuatan ini tidak sejajar dengan apa yang dikehendaki dalam Islam. Para ulama pada dasarnya tidak sepakat dalam menentukan hukum memanfaatkan haiwan jallälah dan ianya terbahagi kepada tiga pandangan. Pandangan pertama, mengharuskan memakan haiwan jallālah sama ada pada daging, susu dan telurnya. Pandangan ini dikemukakan oleh mazhab Maliki.. ${ }^{20}$ Kedua, makruh memanfaatkan haiwan jallälah. Ia dikemukakan oleh mazhab Hanafi ${ }^{21}$ dan Syafii. ${ }^{22}$ Ini adalah kerana wujud bau busuk (najis) pada daging, susu dan telur haiwan berkenaan. Ia boleh dihilangkan dengan mengkuarantinkan haiwan jallālah serta diberikan makanan yang bersih. Hal ini berdasarkan riwayat Ibn 'Umar, bahawa Rasulullah SAW bersabda:

$$
\text { هى رسول الله صلى الله عليه وسلم عن أكل الجحلالة وألباهما }
$$

18 Muḥammad al-Qādir Abū Fāris, Ahkām al-Dhabā'ih fì al-Islām ('Ammān: Dār al-Furqān, 2000), 25.

19 Zaidah Mohd Nor et al., "Makanan Haiwan dan Konsep Jallalah dalam Industri Ternakan Moden," dalam Pengurusan Produk Halal di Malaysia, ed. Suhaimi Ab. Rahman dan Jafri Abdullah (Serdang: Penerbit Universiti Putra Malaysia, 2011), 9.

20 Șāliḥ 'Abd al-Samī' al-Abā al-Aẓharī, Jawāhir al-Iklīl (Mișr: Dār al-Ihyyā' al-Kutub al-'Arabiyyah al-Bābī al-Halabī wa Syirkah, t. t.), 1:216; Abū 'Abd Allāh Muḥammad bin Muḥammad al-Raynī, Mawāhib al-Jalīl li Syarh Mukhtașar Khalīl (Bayrūt: Dār al-Kutub al-'Ilmiyyah, 1995) 4:346; 'Abd al-Raḥman al-Jazīrī, Kitāb al-Fiqh fi al-Madhāhib al-Arba 'ah (Bayrūt: Dār al-Fikr, 1972), 2:5.

21 Zakariyyā 'Alī Yūsuf, Majmū' Syarh al-Muhadhdhab, 2763.

22 Al-Samarqandī, Tuḥfah al-Fuqahā', 65; Abū Isḥāq Ibrahim bin 'Alī al-Syīrāzī, al-Muhadhdhab Fiqh al-Imām al-Syāfi '̄̄, ed. ke-3 (Mișr: Syarikah Maktabah wa Mațba'ah Muștafā al-Bābī al-Halabī wa Awlādih, 1976), 1:332; Zakariyyā 'Al̄̄ Yūsuf, Majmū' Syarh alMuhadhdhab, 26; Abū al-Ḥasan 'Alī bin Muḥammad al-Bașrī, alHāwī al-Kabīr (Bayrūt: Dār al-Kutub al-'Ilmiyyah, 1999), 15:147; Mușțafā Aḥmad Zarqā', Fatāwā Mușțafā al-Zarqā', ed. ke-3 (Dimasyq: Dār al-Qalam, 2004), 225. 
Terjemahan: Rasulullah SAW melarang daripada memakan jallālah dan meminum susunya. ${ }^{23}$

Berdasarkan hadis di atas, Rasulullah SAW telah menegah untuk memakan haiwan jallālah sama ada daripada daging, susu ataupun telurnya. ${ }^{24}$ Al-Khațtābī berpandangan jallālah adalah haiwan seperti unta yang memakan kotoran dan memakan daging dan meminum susunya adalah makruh. Ini adalah kerana haiwan jallālah yang diberikan makanan najis akan meninggalkan bau kotoran daripada badannya. Walaupun demikian, sekiranya haiwan jallālah diternak dan diberikan makanan najis dalam kuantiti yang sedikit, ia tidak dikategorikan sebagai haiwan jallālah. ${ }^{25}$ Al-Syīrāzìi ${ }^{26}$ dalam al-Muhadhdhab fì Fiqh al-Imām al-Syāfi ${ }^{\imath}$ dan Zakariyyā 'Alī Yūsuf dalam Majmū' Syarh al-Muhadhdhab menyatakan makruh memakan haiwan jallälah, iaitu yang banyak memakan tahi sama ada lembu, unta, bebiri dan ayam. ${ }^{27}$ Pandangan al-Samarqandī, dalam kitabnya Tuhfah al-Fuqahä' menyatakan: ${ }^{28}$

Makruh memakan haiwan jallālah termasuklah unta, lembu, dan bebiri kerana kebiasaannya haiwanhaiwan berkenaan memakan najis.

Muștafā al-Zarqā' dalam Fatāwā Muștafā al-Zarqā ${ }^{29}$ menyatakan hukum memakan daging ayam, biri-biri atau lembu jallālah (yang memakan najis) mengikut majoriti mazhab fiqh sehingga ia dikuarantinkan dengan diberi makanan yang bersih. Pandangan ini dipersetujui oleh pandangan Hasan al-Bașrī dalam al-Hāwī al-Kabīr: ${ }^{30}$

23 Hadis riwayat al-Tirmidhī, Kitāb al-Aț'imah, Bāb Mā Jā’a fī Akl Luhūm al-Jallālah wa al-Bānihā, no. hadis 1831. Dan Abū 'Īsā Muhammad bin 'Īsā, Sunan al-Tirmidhī, ed. ke-3 (Bayrūt: Dār alFikr, 1993), 324.

24 Muḥammad 'Abd al-Raḥman al-Mubārakfūrī, Tuhfah al-Aḥwadhī bi Syarh Jamī‘ al-Tïrmidhī, ed. ke-2 (Qāhirah: Maṭba'ah al-Fajālan alJadīdah, 1964), 5:549.

25 Abū Sulaymān Hamād al-Bustī, Ma 'ālim al-Sunan, ed. ke-2 (Bayrūt: Maktabah al-'Ilmiyyah, 1981), 4:244.

26 Al-Syīrāzī, al-Muhadhdhab, 1:332.

27 Zakariyyā 'Alī Yūsuf, Majmū' Syarh al-Muhadhdhab, 26.

28 Al-Samarqandī, Tuhfah al-Fuqahà', 65.

29 Mușțafā Aḥmad Zarqā', Fatāwā Muștafāā al-Zarqā', 225.

30 Al-Bașrī, al-Hāwī al-Kabīr, 15:147. 
Hukum memakan haiwan jallālah adalah makruh dan bukannya haram. Ini kerana, haiwan yang diternak dalam tempat yang bernajis dan diberikan makanan yang tidak halal dalam kuantiti yang banyak menyebabkan bau busuk melekat pada dagingnya. Maka hukum memakan daging, susu dan telurnya adalah makruh. Sekiranya haiwan yang diternak diberikan makanan yang halal dan makanan yang tidak halal, ia tidak dikategorikan sebagai haiwan jallālah. Dan hukumnya adalah halal.

Pandangan fuqaha yang dikemukakan daripada mazhab Hanafi dalam al-Fatāwā al-Hindiyyah ${ }^{31}$ dan Zakariyyā 'Alī Yūsuf ${ }^{32}$ dalam Majmū' Syarh al-Muhadhdhab adalah seperti berikut:

Hukum memakan haiwan jallālah adalah makruh kerana kebiasaannya haiwan-haiwan ini memakan makanan yang kotor atau najis. Ini kerana, makanan yang diambil akan memberikan kesan bau najis kepada tubuh badannya.

Malah, pandangan kontemporari daripada Wahbah Zuhaylī dalam al-Mu'tamad fì Fiqh al-Syäf ' ' $\hat{\imath}^{33}$ menyatakan tidak haram memakan haiwan jallälah dan meminum susunya. Ini adalah berdasarkan sabda Rasulullah SAW:

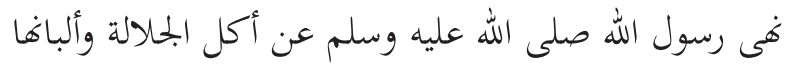

Terjemahan: Rasulullah SAW melarang daripada memakan jallālah dan meminum susunya. ${ }^{34}$

Berdasarkan nas-nas hadis di atas, larangan atau tegahan Rasulullah SAW adalah makrūh tanzīh. Oleh kerana itu, harus mengambil manfaat daripada haiwan jallālah sama ada daging,

31 Niẓām Mușțafā Samīr, al-Fatāwā al-Hindiyyah (Bayrūt: Dār Ihyā̄' al-Turāth al-'Arabī, 2002), 5:428.

32 Zakariyyā 'Alī Yūsuf, Majmū' Syarh al-Muhadhdhab, 26.

33 Wahbah al-Zuhaylī, al-Mu 'tamad al-Fiqh al-Syāfi 'ì (Dimasyq: Dār al-Qalam, 2008), 2:559.

34 Hadis riwayat al-Tirmidhī, Kitāb al-Aț'imah, Bāb Mā Jā’a fī Akl Luhūm al-Jallālah wa al-Bāniha, no. hadis 1831. Dan Abū 'Īsā Muhammad bin 'Īsā, Sunan al-Tirmidhī, 324. 
susu dan telur. Namun, sekiranya haiwan jallālah dikuarantinkan dalam tempoh tertentu maka memakan haiwan jallalah dihalalkan oleh syarak. ${ }^{35}$ Manakala, pandangan ketiga yang dikemukakan oleh mazhab Hanbali ${ }^{36}$ adalah haram mengambil manfaat daripada haiwan jallälah sama ada memakan daging, telur dan susunya. Ini adalah berdasarkan riwayat Ibn 'Umar r.a. sebagaimana yang telah disebutkan sebelum ini.

Al-Maqdīsī dalam al-Iqnā' li Tẩlib al-Intifa ${ }^{37}$ menyatakan pandangannya seperti berikut:

Haram memakan daging, susu, telur haiwan jallālah.

Demikian juga, pandangan al-Mardawī yang menegaskan dalam al-Insāf: $:^{38}$

Diharamkan haiwan jallālah -yang memakan najissusu, telur, sehingga ia dikuarantinkan.

Imam Syafii menegaskan dalam kitabnya al-Umm: ${ }^{39}$

Haram memakan haiwan jallālah sehingga dikuarantinkan dalam beberapa tempoh tertentu bagi menghilangkan bau atau berubah kekotorannya.

Berdasarkan kepada hadis dan pandangan beberapa ulama di atas, pengharaman haiwan jallālah adalah berpunca daripada kebiasaannya yang memakan najis dan wujud unsur najis pada

\section{Ibid.}

36 'Alā' al-Dīn Ab̄̄ al-Hasan al-Mardawī, al-Insāf fì Ma 'rifah al-Rājị̆ min al-Khilāf 'alā Madhhab al-Imām Ahmad bin Hanbal (Bayrūt: Dār al-Iḥyā' al-Turāth al-'Arabī, 1998), 10:275; Syihāb al-Dīn Ab̄̄ al-'Abbās Aḥmad al-Haytamī, Tuhfah al-Muhtāj bi Syarh al-Minhāj (Bayrūt: Dār al-Kutub al-'Ilmiyyah, 2001), 4:275; Muḥammad alSyahīr bin 'Abidīn, 'ala al-Durr al-Mukhtar: Syarḥ al-Tanwīr alAnșār fī Fiqh Madhhab al-Imām Abī Hanīfah al-Nu'mān, Hāsyiyah Radd al-Mukhtār (Bayrūt: Dār al-Fikr, 1992), 6:337.

37 Syarf al-Dīn Mūsā bin Aḥmad al-Maqdīsī, al-Iqnā' 'li Ṭālib al-Intifā ‘ (al-Mamlakah al-'Arabiyyah al-Su'ūdiyyah: Dār 'Ālim al-Kutub, 1999), 4:308.

38 Al-Mardawī, al-Insāf, 10:275

39 Muḥammad bin Idrīs al-Syāfi‘̄i, al-Umm (Bayrūt: Dār al-Kutub al'Ilmiyyah, 2002) 2:379-380. 
daging, susu dan telurnya. Namun, haiwan jallālah yang biasanya diberikan makanan yang bersih dan memakan najis atas sebabsebab tertentu adalah makruh. Ini adalah kerana haiwan ternakan biasanya ia memakan haiwan yang bersih dan bukan najis. ${ }^{40}$ Justeru, pada 4 hingga 6 April 2006, Muzakarah Jawatankuasa Fatwa Kebangsaan kali ke-73 telah membincangkan status kesucian haiwan akuatik yang diberikan makanan tidak halal dan memfokuskan dua komponen yang utama iaitu hukum memakan haiwan jallālah, dan hukum penternak yang memberikan makanan tidak halal kepada haiwan ternakan. Ia dijelaskan seperti mana berikut: ${ }^{41}$

\section{a) Hukum memakan haiwan jallālah}

Antara hujah dan huraian yang dikemukakan oleh ahlijawatankuasa muzakarah fatwa adalah seperti berikut;

Pertama, prinsip asas Islam yang menggalakkan supaya memilih makanan yang halal lagi baik. Firman Allah SWT dalam surah al-Baqarah ayat ke-168:

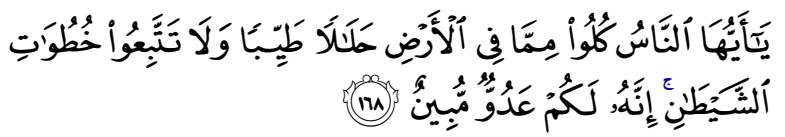

Terjemahan: Wahai sekalian manusia! Makanlah dari apa yang ada di bumi yang halal lagi baik, dan janganlah kamu ikut jejak langkah syaitan; kerana sesungguhnya syaitan itu ialah musuh yang terang nyata bagi kamu.

Kedua, larangan daripada Rasulullah SAW memakan haiwan jallālah. Dalam penentuan status hukum berkenaan memakan ternakan yang memakan najis, ahli muzakarah fatwa telah memilih pandangan yang mengharamkan memakan daging, susu

40 Ghazāfì 'Azzāt al-Ghanānim, al-Istiḥālah wa Aḥkāmuhā fì al-Fiqh al-Islāmī (al-Urdūn: Dar al-Nafa'is, 2008), 189.

41 Mesyuarat Jawatankuasa Fatwa Negeri Selangor "Status Kesucian Ikan Yang Diberi Makanan Tidak Halal," Bil (10) dlm. Mufti 5003/2. Lihat juga, Kertas untuk Pertimbangan Muzakarah Jawatakuasa Fatwa Majis Kebangsaan Bagi Hal Ehwal Ugama Islam Malaysia, Kertas JKF bil. 2/73/2006. 
dan telur haiwan jallälah. Ini adalah berdasarkan pandangan daripada mazhab Syafii yang menyatakan haiwan jallālah adalah haram dimakan. Dalilnya adalah daripada sabda Rasullullah SAW bahawa:

$$
\text { هى رسول الله صلى الله عليه وسلم عن أكل الجلالة وألباها }
$$

Terjemahan: Rasulullah SAW melarang daripada memakan jallālah dan meminum susunya. ${ }^{42}$

Pandangan ini berpegang dengan zahir hadis di atas bahawa Rasulullah SAW secara jelas menegah daripada memakan daging jallālah dan meminum susunya. Walaupun begitu, haiwan jallālah yang dikuarantinkan selama beberapa tempoh tertentu akan menyebabkan segala kekotoran atau kenajisan yang berada dalam tubuh haiwan jallālah dihilangkan dan hukum memakannya adalah harus.

b) Hukum penternak memberikan makanan tidak halal kepada haiwan ternakan

Para fuqaha mazhab Syafii turut membahaskan hukum penternak yang memberikan makanan tidak halal kepada haiwan ternakan. Mazhab Syafii mengharuskan penternak memberikan makanan daripada najis atau yang bercampur dengan najis (mutanajjis) kepada haiwan ternakan dan harus memberikan minum air yang telah berubah sifatnya kepada haiwan dan ternakan. Di samping itu, Muzakarah Jawatankuasa Fatwa Kebangsaan Bagi Hal Ehwal Ugama Islam Malaysia Kali Ke-2 yang bersidang pada 12-13 Mei 1981 telah membincangkan hukum baja daripada tahi babi dan memutuskan seperti berikut:

Bahawa baja yang diperbuat daripada tahi babi adalah najis berat (mughallazah), sementara hukum menggunakannya sebagai baja adalah harus serta makruh.

Bahawa makanan ayam yang diproses daripada bahan-bahan yang bercampur dengan najis seperti

42 Hadis riwayat al-Tirmidhī, Kitāb al-Aț'imah, Bāb Mā Jā’a fī Akl Luhūm al-Jallālah wa al-Bāniha, no. hadis 1831. Dan Abū 'Īsā Muhammad bin 'Īsā bin Sawrah, Sunan al-Tirmidhī, 324 


\section{darah lembu, darah babi dan lain-lain adalah harus atau halal.}

Walau bagaimanapun, setelah membincangkan dan menimbang hujah-hujah yang dikemukakan dalam isu ini, mensyuarat Panel Kajian Syariah Kali Ke-54 yang bersidang pada 23-25 Februari 2006 telah mengambil keputusan bahawa haram memakan ikan ternakan yang diberikan makanan tidak halal seperti babi ataupun bangkai. Ini sebagai langkah berhati-hati dan menjaga sensitiviti masyarakat Islam di Malaysia. Berdasarkan fatwa yang dikeluarkan oleh Muzakarah Jawatankuasa Fatwa Kebangsaan, dapat dirumuskan bahawa pengharaman ke atas status kesucian ikan yang diberikan makanan tidak halal adalah berasaskan kepada keterikatan mazhab Syafii yang masih kukuh di Malaysia. Tambahan pula, fatwa ini dikeluarkan berasaskan rujukan terhadap fatwa-fatwa terdahulu dan rujukan karya-karya fiqh mazhab Syafii. Bahan rujukan utama dalam penyelidikan fatwa ini adalah kitabkitab klasik, kontemporari dan buku berbahasa melayu.

Antara karya-karya yang menjadi rujukan Muzakarah Jawatankuasa Fatwa Kebangsaan adalah Mughnī al-Muhtāj karangan al-Syarbīnī, Rawdah al-Tälibìn karangan al-Nawawī, alFatāwā min Ahsan al-Kalām fì al-Fatāwā wa al-Ahkēm, karangan 'Ațiyyah Saqr, al-Aț'imah wa al-Dhabā'ih fì al-Fiqh al-Islāmī, al-Fiqh al-Islāmī wa Adillatuh karangan Wahbah al-Zuhaylī, alMawsū'ah al-Fiqhiyyah karangan Wizārah al-Awqāf wa al-Syu'ūn al-Islāmiyyah dan Seratus (100) Masalah Agama karangan KH.M. Sjafi'i Hadzami. Di samping itu, fatwa ini mengaplikasikan prinsip sadd al-dhara ${ }^{\prime} i$ ' bagi menjaga sensitiviti masyarakat Islam di Malaysia.

Mufti Kerajaan Negara Brunei Darussalam, pada Siri Fatwa (35/2006) telah mengeluarkan fatwa yang bertajuk "Makan Ikan Yang Diberi Makan Najis" bagi menjawab pertanyaan daripada masyarakat awam mengenai hukum haiwan jallālah. Justeru, persoalan ini dijelaskan dalam beberapa hujah dan alasan seperti berikut: ${ }^{43}$

43 Fatwa Mufti Kerajaan Negara Brunei Darussalam, Makan Ikan Yang Diberi Makan Najis, Siri Fatwa 35/2006. 
Pertama, hukum memakan haiwan jallālah. Hukum memakan haiwan jallālah adalah makruh. Ini adalah berdasarkan kepada sabda Rasulullah SAW yang diriwayatkan oleh Ibn 'Umar r.a.:

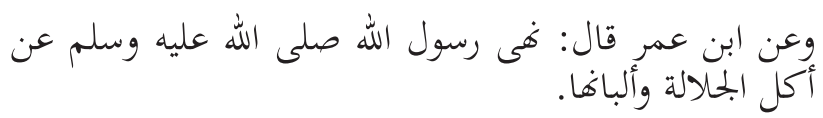

Terjemahan: Rasulullah melarang daripada memakan haiwan jallālah dan meminum susunya. ${ }^{44}$

Al-Nawāwī di dalam al-Majmū' menyatakan tegahan dalam hadis di atas adalah bersifat makruh apabila daging atau susu haiwan jallālah berbau seperti bau najis. ${ }^{45}$ Perkara ini ditegaskan lagi oleh al-Malībārī r.a. dengan katanya:

Dan makruh hukumnya memakan daging binatang jallālah sekalipun bukan dari jenis binatang ternakan (unta, lembu dan kambing) seperti ayam jika terdapat padanya bau najis.

Sayyid al-Bakrī menambah bahawa seumpama bau juga ialah rasa dan warna sebagaimana ibarat yang digunakan oleh Ibn Hajar di dalam Tuhfah al-Muhtäj. Disebut di sini bau sahaja kerana bau daging haiwan jallālah kebiasaannya akan berubah seperti bau najis. Tetapi jika daging haiwan jallālah tidak berubah rasa, warna atau baunya seperti najis, maka adalah harus dan tidak makruh hukumnya memakan daging haiwan jallālah tersebut sekalipun haiwan jallālah tidak makan kecuali yang najis sahaja. Begitu juga, haiwan jallālah yang dikuarantin dan diberikan dengan makanan yang bersih sehingga hilang bau kenajisan, kemudian ia disembelih maka hukum memanfaatkannya adalah diharuskan oleh syarak. Manakala, kuantiti makanan yang diberikan dan kadar tempoh kuarantinan haiwan jallālah tidak ditentukan dan ianya tertakluk kepada adat kebiasaan atau sangkaan bau najis sudah hilang. Dalam kitab Hāsyiyah al-Syarqawĩ:

Tiada kadar (yang tepat) bagi tempoh masa memberi makan (untuk menghilangkan kesan najis).

\footnotetext{
44 Hadis riwayat al-Tirmidhī, Kitāb al-Aț'imah, Bāb Mā Jā’a fī Akl Luhūm al-Jallālah wa al-Bānihā, no. hadis 1831. Dan Abū 'Īsā Muḥammad bin 'Īsā bin Sawrah, Sunan al-Tirmidhī, 324

45 Zakariyyā 'Alī Yūsuf, Majmū' Syarh al-Muhadhdhab, 26.
} 
Penentuan kadar tempoh masa dengan empat puluh hari pada unta, tiga puluh hari pada sapi, tujuh hari pada kambing dan tiga hari pada ayam adalah berdasarkan adat kebiasaan sahaja. Maka jika hilang (kesan najis) dengan mengambil tempoh masa yang kurang daripadanya, maka tempoh masa itu boleh diiktibar (sebagai tempoh masa yang dapat menghilangkan kesan najis), atau tidak hilang (kesan najis) dengan tempoh masa yang tersebut, maka tempoh masa yang diiktibar (sebagai tempoh masa yang boleh menghilangkan kesan najis) hendaklah dengan menambah kadar tempoh masa-masa yang tersebut ini.

Kedua, hukum penternak memberikan makanan tidak halal kepada haiwan ternakan adalah makruh. Ini adalah berdasarkan pandangan Ibn Hajar di dalam Tuhfah al-Muhtāj: ${ }^{46}$

Dan makruh hukumnya memberikan makanan kepada haiwan yang boleh dimakan dengan benda najis (seperti tahi dan babi).

Ketiga, hukum penjualan haiwan jallālah. Haiwan jallālah yang disembelih tanpa dikuarantinkan hukumnya adalah makruh kerana rasa, warna dan bau najis masih kekal dibadannya. Ini adalah menurut kaedah li al-wasā'il hukm al-maqāșid yang bermaksud bagi perkara-perkara yang menjadi jalan-jalan (menuju ke arah berlakunya suatu tujuan), (hukumnya adalah seperti) hukum tujuantujuannya. Walau bagaimanapun, sekiranya haiwan jallālah dijual dalam keadaan hidup dan boleh dikuarantinkan untuk diberikan makanan yang bersih agar segala kekotoran dapat dihilangkan daripada badannya maka hukum menjual haiwan jallālah adalah harus. Oleh yang demikian, ahli muzakarah fatwa Negara Brunei Darussalam memutuskan bahawa tidak haram memakan ikan yang diberi makanan najis. Tetapi, sekiranya daging ikan berubah rasa, bau atau warnanya seperti najis, hukumnya adalah makruh. Sebaliknya, jika rasa, bau atau warnanya tidak berubah hukum memakannya adalah diharuskan oleh syarak.

46 Ibn Hajar al-Haytamī, Tuḥfah al-Muhtāj, 275. 
Berdasarkan fatwa Negera Brunei Darussalam, analisis menunjukkan bahawa memanfaatkan haiwan jallālah sebagai makanan dan penjualan adalah makruh. Ini adalah berdasarkan kepada nas-nas hadis yang meriwayatkannya. Fatwa ini dikeluarkan berasaskan rujukan karya-karya fiqh klasik antaranya Hayāh al-Hayawān al-Kubrā karangan Kamāl al-Dīn al-Ḍamirī, Majmū' karangan al-Nawāwī, Tuhfah al-Muhtāj karangan Ibn Hajar, I 'ānah al-Tālibīn karangan Abū Bakr Ibn Muhammad Syatā dan Hīsyiyah al-Syarqawī karangan al-Syarqawī.

\section{PERBINCANGAN DAN RUMUSAN}

Berdasarkan kepada keputusan fatwa yang dikeluarkan oleh Muzakarah Jawatankuasa Fatwa Kebangsaan dan Mufti Kerajaan Negara Brunei Darussalam, ketidaksamaan hukum terhadap haiwan jallālah adalah berpunca daripada perbezaan dalam penentuan standard makanan halal dan perbezaan sumber rujukan. Metode pengambilan fatwa daripada Majlis Jawatankuasa Fatwa Kebangsaan telah mengaplikasikan kaedah nas al-Quran dan hadis, serta rujukan kepada karya-karya fiqh. Namun, pada pengamatan penulis rujukan terhadap nas daripada al-Quran dan hadis hanya dibuat dalam bentuk petikan ayat, terjemahan dan penjelasan yang ringkas tanpa rujukan kepada penafsiran al-Quran dan huraian hadis secara mendalam dan terperinci. Sedangkan, rujukan terhadap kedua-dua sumber ini sangat penting dalam proses pengeluaran fatwa. Ini kerana, al-Quran dan hadis merupakan sumber yang muktabar dalam penentuan hukum Islam. Di samping itu, ahli jawatankuasa fatwa banyak merujuk kepada kitab-kitab kontemporari seperti al-Aț 'imah wa al-Dhabä'ih fì alFiqh al-Islāmī, al-Fiqh al-Islāmī wa Adillatuh karangan Wahbah al-Zuḥaylī, al-Mawsu'ah al-Fiqhiyyah karangan Wizārah alAwqāf wa al-Syu'ūn al-Islāmiyyah dan Seratus (100) Masalah Agama karangan KH.M. Sjafi'i Hadzami tanpa merujuk kepada kitab-kitab turāth daripada mazhab Syafii yang lain. Jawatankuasa fatwa juga banyak menyalin pandangan-pandangan yang terdapat di dalam kitab-kitab kontemporari dalam proses penyediaan fatwa mereka. Kitab-kitab kontemporari tidak boleh dijadikan sebagai sandaran utama dalam pendalilan fatwa. Ini kerana, perbincangan dalam kitab-kitab kontemporari hanya memuatkan pandangan yang umum. Sedangkan jika diteliti kitab-kitab turäth mazhab yang 
asal banyak sekali pandangan fuqaha yang boleh dikaitkan dengan haiwan jallālah. ${ }^{47}$ Meskipun begitu, kitab-kitab kontemporari boleh dirujuk sebagai rujukan sampingan yang boleh membantu atau menyokong pendalilan fatwa. Akan tetapi, tidak dapat dinafikan bahawa ahli jawatankuasa fatwa turut merujuk kepada kitab-kitab turāth daripada mazhab Syafii antaranya Mughnī alMuhtāj karangan Muḥammad al-Khāțib al-Syarbīnī, Rawdah alTặlibīn karangan al-Nawawī dan al-Fatāwā min Ahsan al-Kalām fì al-Fatāwā wa al-Aḥkām karangan 'Ațiyyah Saqr.

Metode pengambilan fatwa Mufti Kerajaan Negara Brunei Darussalam mengaplikasikan kaedah rujukan kepada nas hadis, serta rujukan terhadap karya-karya fiqh turäth. Pada pengamatan penulis juga, metode penafsiran yang digunakan Mufti Kerajaan Negara Brunei Darussalam lebih jelas kerana merujuk kepada nas hadis dan kemudiannya dihuraikan melalui pandangan-pandangan ulama fiqh. Selain itu, ia merujuk kepada sumber-sumber primer iaitu karya-karya turāth seperti Hayāh al-Hayawān al-Kubrā karangan Kamāl al-Dīn al-Ḍamirī, Majmū' karangan al-Nawawī, Tuhfah al-Muḥtāj karangan Ibn Hajar al-Haytamī, I'ānah alṬălibìn karangan Abū Bakr Ibn Muḥammad Syatā dan Hāsyiyah al-Syarqawī karangan al-Syarqawī dalam proses pengeluaran fatwa dan tidak menggunakan sumber-sumber rujukan sekunder yang lain. Huraian konsep dan hukumnya adalah jelas, padat dan mudah difahami oleh masyarakat awam. Oleh kerana itu, pandangan jumhur ulama dijadikan pandangan hukum oleh Mufti Kerajaan Negara Brunei Darussalam mengenai isu kehalalan haiwan jallālah berkenaan.

Merujuk kepada Garis Panduan Umum Malaysian Standard MS 1500: $2009^{48}$ perkara 3.5.1.1.2, mencatatkan bahawa hukum memakan haiwan akuatik yang diberikan makanan tidak halal secara berterusan adalah haram. Ia juga tidak menepati piawaian makanan halal, perkara 2.3, serta dikategorikan sebagai najis,

47 Mohd Faez Mohd Shah, "Pengambilkiraan Realiti Semasa dalam Berfatwa: Analisis Fatwa-fatwa Mufti Kerajaan Negeri Johor dari Tahun 2000 hingga 2009" (disertasi, Jabatan Fiqh dan Usul Akademi Pengajian Islam, Universiti Malaya, 2009/2010), 79.

48 Jabatan Standard Malaysia, Malaysia Standard MS 1500:2009 Makanan Halal: Pengeluaran, Penyediaan, dan Penyimpanan- Garis Panduan Umum (Semakan Kedua), 6. 
seksyen 2.4.1 (a),(b),(c), iaitu najis mughallazah, perkara 2.4.2 (a). Berdasarkan piawaian ini, penternak ikan di Malaysia khususnya penternak air tawar perlu mempraktikkan tempoh kurungan untuk ikan sebelum dipasarkan. Ia sedikit berbeza dalam Brunei Darussalam Standard Halal Food PBD24:2007 perkara 3.1.1.2, ${ }^{49}$ yang mana status kehalalan haiwan akuatik yang diberikan makanan tidak halal tidak dinyatakan secara terperinci.

\section{KESIMPULAN}

Islam sentiasa menyeru umatnya supaya memakan makanan yang halal lagi baik. Dalam isu ini, penulis berpandangan keputusan Muzakarah Jawatankuasa Fatwa Kebangsaan Bagi Hal Ehwal Ugama Islam Malaysia adalah lebih tepat dengan realitinya di Malaysia. Langkah ini diambil untuk mencegah keburukan yang lebih besar kesannya ke atas masyarakat awam di Malaysia. Hukum pengharaman memakan ikan yang diberikan makanan tidak halal adalah sebagai langkah berhati-hati dan sadd aldhara ' $i$ ' demi menjamin kesucian melaksanakan ibadah dalam kehidupan. Tegahan ini juga diambil untuk tidak membuka ruang kepada penternak-penternak haiwan akuatik mengambil cara mudah untuk memelihara haiwan akuatik dengan memberikan makanan yang tidak halal dan kotor kepada haiwan berkenaan. Selain itu, analisis mendapati kebanyakan penternak haiwan akuatik adalah terdiri daripada golongan bukan Islam dan tahap pengetahuan mereka terhadap konsep halal masih lagi rendah. Oleh kerana itu, langkah sadd al-dharā' ' ${ }^{\prime}$ adalah satu pendekatan yang baik sekali gus bagi menjaga 'urf dan sensitiviti masyarakat Islam di Malaysia. Kaedah sadd al-dharā' $i$ " perlu diambil kira dalam penentuan hukum kerana penternak mempunyai banyak pilihan makanan halal dan bersih yang boleh dijadikan makanan untuk ikan. Sekiranya jawatankuasa memutuskan hukum memakan ikan-ikan yang diberikan makanan najis ini sebagai makruh, pembuatan mengekploitasi hukum tersebut akan timbul dan akan lebih mengelirukan umat Islam. Prinsip halālan tayyiban dalam makanan perlu diberikan ketegasan dalam isu ini. Walau bagaimanapun, fatwa yang diputuskan oleh negara Brunei

49 Religious Council Brunei Darussalam, Brunei Darussalam Standard Halal Food PBD 24:2007, 10. 
Darussalam adalah bertepatan dengan realiti semasa dan budaya setempat dalam negara berkenaan. Ini kerana, Brunei merupakan sebuah negara Islam yang mengharamkan kemasukan haiwan yang tidak halal seperti babi. Maka kebarangkalian pemberian makanan tidak halal kepada haiwan akuatik tidak mungkin berlaku. Bahkan kawalan bagi kemasukan makanan dan barangan halal dikawal secara ketat dan sepenuhnya di bawah Bahagian Kawalan Makanan Halal di Negara Brunei Darussalam.

\section{BIBLIOGRAFI}

Abū 'Īsā Muhammad bin 'Īsā. Sunan al-Tirmidhī. Ed. ke-3. Bayrūt: Dār al-Fikr, 1993.

Al-Aẓharī, Șālih 'Abd al-Samī' al-Abā. Jawāhir al-Iklīl. Miṣr: Dār al-Iḥyā' al-Kutub al-'Arabiyyah al-Bābī al-Ḥalabī wa Syirkah, t. t.

Al-Bașrīe Abū al-Ḥasan 'Alī bin Muḥammad bin Habib alMawardī. Al-H̄̄ầ al-Kabīr. Bayrūt: Dār al-Kutub al'Ilmiyyah, 1999.

Bernama. "Waspada Beli Ikan Air Tawar Diberi Makan Daging Babi." Laman sesawang Kementerian Perdagangan Dalam Negeri, Koperasi dan Kepenggunaan. Dicapai 16 Januari 2015. http://kpdnkk.bernama.com/newsBm. php?id=175968\&.

Al-Bustī, Abū Sulaymān Ḥamād al-Khaț̣āāin. Ma'ālim al-Sunan. Ed. ke-2. Bayrut: Maktabah al-'Ilmiyyah, 1981.

Fatwa Mufti Kerajaan Negara Brunei Darussalam. "Makan Ikan Yang Diberi Makan Najis." Siri Fatwa (35/2006).

Fazrina Ayu Raduian. "Ikan Diberi Makan Bangkai Babi." Laman sesawang Utusan Malaysia. http://www.utusan.com. my/utusan/Dalam_Negeri/20140710/dn_16/Ikan-diberimakan-bangkai-bāibi. Dicapai 16 Januari 2015.

Ghazāfī 'Azzāt al-Ghanānim. Al-Istiḥālah wa Aḥkāmuhā fì alFiqh al-Islāmā. Al-Urdun: Dār al-Nafā’ is, 2008.

Jabatan Kemajuan Islam Malaysia. "Status Kesucian Ikan Diberi Makanan Tidak Halal." Laman sesawang Portal Rasmi Fatwa Malaysia. Dicapai 16 Januari 2015. http://www.e- 
fatwa.gov.my/fatwa-negeri/status-kesucian-ikan-diberimakanan-tidak-halal-0.

Al-Jazīrī, 'Abd al-Raḥman. Al-Fiqh fì al-Madhāhib al-Arba 'ah. Bayrūt: Dār al-Fikr, 1972.

Kertas untuk Pertimbangan Muzakarah Jawatankuasa Fatwa Majlis Kebangsaan Bagi Hal Ehwal Ugama Islam Malaysia, Kertas JKF Bil. 2/73/2006.

Al-Maqdīsī, Syarf al-Dīn Mūsā. Al-Iqnā' li Ṭālib al-Intifā' ' alMamlakah al-'Arabiyyah al-Su'ūdiyyah: Dār 'Ālim alKutub, 1999.

Maḥmūd 'Abdal-Raḥman 'Abd al-Mun'im. Mu 'jam al-Mușțalahāt wa Alfāz al-Fiqhiyyah. Al-Qāhirah: Dār al-Faḍilah, t. t.

Al-Mardawī, 'Alā' al-Dīn Abī al-Hasan. al-Insāf. Bayrūt: Dār alIhyyā’ al-Turāth al-'Arabī, 1998.

Al-Mawsū'ah al-Fiqhiyyah. Ed. ke-2. Al-Kuwayt: Wizārah alAwqāf wa al-Syu'ūn al-Islāmiyyah, 2007.

Mesyuarat Jawatankuasa Fatwa Negeri Selangor. "Status Kesucian Ikan Yang Diberi Makanan Tidak Halal." Bil (10) dlm. Mufti 500-3/2.

Mohd Faez Mohd Shah. "Pengambilkiraan Realiti Semasa dalam Berfatwa: Analisis Fatwa-Fatwa Mufti Kerajaan Negeri Johor dari Tahun 2000 hingga 2009" (disertasi, Jabatan Fiqh dan Usul Akademi Pengajian Islam, Universiti Malaya, 2009/2010).

Al-Mubārakfūrī, Muḥammad 'Abd al-Raḥman. Tuhfah al-Aḥwadhī bi Syarh Jamī' al-Tirmidhī. Ed ke-2. Qāhirah: Mațba'ah alFajālan al-Jadīdah, 1964

Muḥammad al-Qādir Abū Fāris. Ahkē̄m al-Dhabā'ih fì al-Islām. 'Ammān: Dār al-Furqān, 2000.

Muḥammad al-Syahīr bin 'Abidīn 'ala al-Durr al-Mukhtar: Syarḥ al-Tanwīr al-Anșār fī Fiqh Madhhab al-Imām Abī Hanīfah. Hāsyiyah Radd al-Mukhtār. Bayrūt: Dār al-Fikr, 1992.

Muștafā Aḥmad Zarqā'. Fatāwā Mușțafā al-Zarqā'. Ed. ke-3. Dimasyq: Dār al-Qalam, 2004.

Nizāām Mușțafā Samīr. Al-Fatāwā al-Hindiyyah. Bayrūt: Dār Iḥyā’ 
al-Turāth al-'Arabī, 2002.

Al-Muqrab̄̄, Abū 'Abd Allāh Muḥammad. Mawāhib al-Jalīl.. Bayrūt: Dār al-Kutub al-'Ilmiyyah, 1995

Sa'di Abū Jayb. Al-Qāmūs al-Fiqh Lughatan wa Iștilāhan. Dimasyq: Dār al-Fikr, 2009.

Al-Samarqandī, 'Ilā' al-Dīn Muḥammad bin Aḥmad. Tuhfah alFuqahā'. Bayrūt: Dār al-Kutub al-'Ilmiyyah, t. t.

Al-Syīrāzī, Abū Isḥāq Ibrahim. Al-Muhadhdhab.. Ed. ke-3. Mișr: Syarikah Maktabah wa Maṭba 'ah Muștafā al-Bābī al-Ḥalab̄i wa Awlādih, 1976.

Al-Syāfi'ī, Muḥammad bin Idrīs. Al-Umm. Bayrūt: Dār al-Kutub al-'Ilmiyyah, 2002.

Al-Haytamī, Syihāb al-Dīn Ab̄̄ al-'Abbās. Tuhfah al-Muhtāj bi Syarḥ al-Minhāj. Bayrūt: Dār al-Kutub al-'Ilmiyyah, 2001.

The Religious Council Brunei Darussalam. Brunei Darussalam Standard Halal Food PBD 24:2007. Brunei: The Religious Council Brunei Darussalam, 2007.

Wan Norhana Md. Noordin. "Haiwan Al-Jallalah." http://dbserver. fri.gov.my/portal/portalimages/buku-penerbitan/Kosmik sep2012_wan.pdf. Dicapai 28 Februari 2014.

Zaidah Mohd Nor et al. "Makanan Haiwan dan Konsep Jallalah dalam Industri Ternakan Moden." Dalam Pengurusan Produk Halal di Malaysia. Ed. Suhaimi Ab. Rahman dan Jafri Abdullah (Serdang: Penerbit UPM, 2011), 9.

Zakariyyā 'Alī Yūsuf. Majmū' Syarh al-Muhadhdhab. t. p.: t. t. p, t. t.

Al-Zuhaylī, Wahbah. Al-Mu'tamad al-Fiqh al-Syāfi 'ī. Dimasyq: Dār al-Qalam, 2008. 